\title{
Vehicular emission of volatile organic compounds (VOCs) from a tunnel study in Hong Kong
}

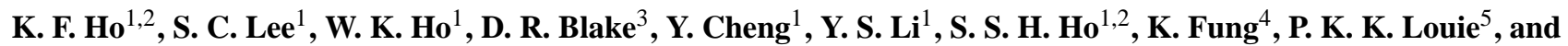 \\ D. Park $^{6}$ \\ ${ }^{1}$ Department of Civil and Structural Engineering, Research Center for Environmental Technology and Management, The \\ Hong Kong Polytechnic University, Hung Hom, Kowloon, Hong Kong, China \\ ${ }^{2}$ SKLLQG, Institute of Earth Environment, Chinese Academy of Sciences, Xi'an, 710075, China \\ ${ }^{3}$ Department of Chemistry, University of California, Irvine, USA \\ ${ }^{4}$ AtmAA Inc., 23917 Craftsman Road, Calabasas, CA 91302, USA \\ ${ }^{5}$ Hong Kong Environmental Protection Department, 47/F, Revenue Tower, 5 Gloucester Road, Wan Chai, Hong Kong, China \\ ${ }^{6}$ Railroad Environment Research Department, Korea Railroad Research Institute, Gyeonggi-Do, Korea
}

Received: 23 April 2009 - Published in Atmos. Chem. Phys. Discuss.: 2 June 2009

Revised: 13 August 2009 - Accepted: 10 September 2009 - Published: 7 October 2009

\begin{abstract}
Vehicle emissions of volatile organic compounds (VOCs) were determined at the Shing Mun Tunnel, Hong Kong in summer and winter of 2003. One hundred and ten VOCs were quantified in this study. The average concentration of the total measured VOCs at the inlet and outlet of the tunnel were $81250 \mathrm{pptv}$ and $117850 \mathrm{pptv}$, respectively. Among the 110 compounds, ethene, ethyne and toluene were the most abundant species in the tunnel. The total measured VOC emission factors ranged from $67 \mathrm{mg} \mathrm{veh}^{-1} \mathrm{~km}^{-1}$ to $148 \mathrm{mg} \mathrm{veh}^{-1} \mathrm{~km}^{-1}$, with an average of $115 \mathrm{mg} \mathrm{veh}^{-1} \mathrm{~km}^{-1}$. The five most abundant VOCs observed in the tunnel were, in decreasing order, ethene, toluene, $n$-butane, propane and $i$-pentane. These five most abundant species contributed over $38 \%$ of the total measured VOCs emitted. The high propane and $n$-butane emissions were found to be associated with liquefied petroleum gas (LPG)-fueled taxis. Fair correlations were observed between marker species (ethene, $i$-pentane, $n$-nonane, and benzene, toluene, ethylbenzene and xylenes BTEX) with fractions of gasoline-fueled or diesel-fueled vehicles. Moreover, ethene, ethyne, and propene are the key species that were abundant in the tunnel but not in gasoline vapors or LPG. The ozone formation potential from the VOCs in Hong Kong was evaluated by the maximum increment reactivity (MIR). It was found to be $568 \mathrm{mg}$ of ozone
\end{abstract}

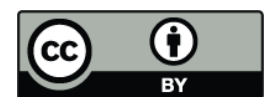

Correspondence to: S. C. Lee (ceslee@polyu.edu.hk) per vehicle per kilometer traveled. Among them, ethene, propene and toluene contribute most to the ozone-formation reactivity.

\section{Introduction}

Vehicular emissions are one of major sources of volatile organic compounds (VOCs) in the urban areas throughout the Pearl River Delta Region in China. The VOCs (e.g. benzene and 1,3-butadiene) emitted from vehicles directly influence human health due to their toxicity as well as are precursors for the formation of ozone $\left(\mathrm{O}_{3}\right)$ and other photo-oxidants in ambient air (Finlayson-Pitts and Pitts, 1986). VOCs also play an important role in the formation of ground-level $\mathrm{O}_{3}$ and photochemical oxidants associated with urban smog (Monod et al., 2001). Photochemical smog is now an everyday occurrence in many urban areas throughout the world. Smog is a mixture of secondary pollutants such as $\mathrm{O}_{3}$, nitrogen dioxide $\left(\mathrm{NO}_{2}\right)$, nitric acid $\left(\mathrm{HNO}_{3}\right)$, aldehydes and other organic compounds, formed from photochemical reactions between nitrogen oxides $\left(\mathrm{NO}_{\mathrm{x}}\right)$ and hydrocarbons.

There are two widely used methods to determine vehicular emission profiles: chassis dynamometer tests and direct measurements in roadway tunnels. These two types of measurements strongly vary with many factors, such as vehicular engine types (e.g. gasoline fueled and diesel fueled engines)

Published by Copernicus Publications on behalf of the European Geosciences Union. 
and engine operating conditions (e.g. cruising, idling, and transient modes) (Kaiser et al., 1992; Heeb et al., 1999, 2000; Tsai et al., 2003). With the chassis dynamometer tests, operating conditions and fuel compositions can be adjusted and controlled, thus it has ability to examine vehicular emissions under different driving or loading settings and to effectively evaluate exhaust control technologies (Ning et al., 2008). Moreover, it is an ideal tool to distinguish between exhaust and evaporative emissions at a well-regulating environment (Liu et al., 2008). The drawbacks of chassis dynamometer test are expensive and time consuming in set-up. In addition, it cannot reflect the emissions from a real world traffic environment where a composite of different on-road vehicles are being operated. For these reasons, another approach of roadway tunnel measurement has been developed and applied to determine vehicular emissions in the past decade (e.g. Pierson et al., 1990; Haszpra and Szilagyi, 1994; Gertler et al., 1996; Duffy and Nelson, 1996; Mugica et al., 1998; Stemmler et al., 2005; Chiang et al., 2007). It directly determines vehicular emission profiles and rates at a complicated on-road condition which mixes with emissions from vehicle tailpipes, unconsumed gasoline, and vehicle evaporative emissions. The result obtained is thus more representative and accurate in estimation of emissions from a large number of vehicles to the local urban areas (Lonneman et al., 1986). The roadway tunnel measurements have several assumptions and limitations, including no cold start emissions, bias in fleet distributions, resistance caused by tunnel walls, and speed limits inside the tunnels.

Many tunnel studies reported the emission factors of individual and total VOCs. Stemmler et al. (1995) measured the emissions of carbon monoxide (CO), sulfur dioxide $\left(\mathrm{SO}_{2}\right)$, $\mathrm{NO}_{\mathrm{x}}$, and 26 individual VOCs including alkanes and aromatic hydrocarbon in Gubrist tunnel in Switzerland in 1993. The emission factors of the total hydrocarbons are 426.5 and $432.5 \mathrm{mg} \mathrm{km}^{-1}$ for all vehicles and light duty vehicles, respectively.

In 2002, they have done a monitoring at the same location and found that the emission factors of particular VOCs were sufficiently lower than the values obtained in 1993 (Stemmler et al., 2005). For instance, the emission factors of benzene and toluene decreased from 13.69 to $2.7 \mathrm{mg} \mathrm{km}^{-1}$ and 26.27 to $6.4 \mathrm{mg} \mathrm{km}^{-1}$, respectively. The figures indicate that the efficient technology of modern car fleets with respect to VOCs emissions. In Taiwan, research also reported that paraffins and aromatics are the main VOCs groups in the tunnel (Chiang et al., 2007). The emission factors of total non-methane hydrocarbon (NMHC) were $440-1500 \mathrm{mg} \mathrm{km}^{-1}$ (Chiang et al., 2007; Haw et al., 2002; Hsu et al.,2001).

Hong Kong is a densely populated city. According to the Hong Kong Transportation Department, there were 532872 licensed vehicles in December 2004. Several ambient studies have recently been completed indicating vehicular emissions are the most important source for VOCs in Hong Kong (Lee et al., 2001; Ho and Lee, 2002; Guo et al., 2004). Liquefied petroleum gas (LPG), gasoline, and diesel are the main fuels used by vehicles in Hong Kong. In 2004, gasoline fueled vehicles accounted for $70.4 \%$ of the total licensed vehicles, while diesel and LPG fueled vehicles accounted for $24.5 \%$ and 3.5\%, respectively (Hong Kong Transport Department, 2004). Vehicular performance affects fuel consumption and emissions in part because it would affect the combustion efficiency and evaporative emissions from the fuel system. On the contrary, Turrio-Baldassarri et al. (2004) reported that synthesis and application of different types of fuels, modifications of engine designs, and improving emission control and catalytic technologies cause variations in emissions.

In Pearl River Delta Region, only researches (e.g. Guo et al., 2007; Chan et al., 2006; Barletta et al., 2005; Ho et al., 2004; Lee et al., 2002) reported the urban levels of VOCs. To our best knowledge, there are only limited measurementbased VOC emission profiles available in Hong Kong. This is a pilot study to determine local VOC emission profiles from vehicular exhaust. Air samples were collected in the heavy usage tunnel during winter and summer in 2003. The project also developed a reliable monitoring program to determine the emission factors of VOCs. The emission factors were estimated by measuring the concentration differences between the tunnel inlet and outlet, the traffic rates, and the tunnel ventilation flux during sampling periods. The in-depth understanding provides important information for management of Hong Kong air quality.

\section{Methodology}

\subsection{Sampling location - Shing Mun Tunnel}

Shing Mun Tunnel composes of two sections, Smugglers Ridge side and Needle Hill side, and the monitoring stations are located at the Needle Hill sides of the Shing Mun Tunnel. The length of the section selected is approximately $1.6 \mathrm{~km}$ (Fig. 1). Shing Mun Tunnel is a two-bore tunnel (north bore and south bore) with two lanes of traffic per bore (without walkways), and is currently used on average by 53300 vehicles per day (2004 Annual Traffic Census in Hong Kong). Two sampling stations were located in the south bore (Fig. 1), with vehicle flow from Shatin to Tsuen Wan. The length of the west side of the tunnel is approximately $1.6 \mathrm{~km}$ and there is an upgrade of $5.4 \%$ approaching the tunnel. The cross sectional area of the tunnel is $70.0 \mathrm{~m}^{2}$. The vehicle speed limit is $80 \mathrm{~km} \mathrm{~h}^{-1}$. There is no fresh air supply throughout the bores, therefore, the dilution factor of air pollutants was eliminated. The ventilation mode is longitudinal, which is achieved from the piston effect of the vehicles traversing it. There are 80 jet and four exhaust-air fans positioned along the ceiling throughout the tunnel but were all inactivated during sampling periods. The ventilation was thus induced by the flow of traffic through the tunnel and prevailing winds only. The average wind speeds in the tunnel were measured 


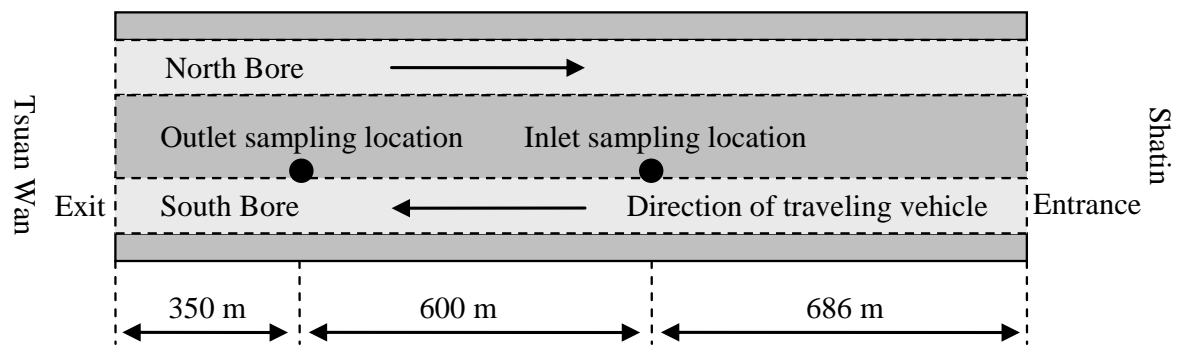

Fig. 1. Schematic diagram of the Shing Mun Tunnel.

by the two sensors installed on the top roof of the tunnel near the sampling stations.

\subsection{Sampling and instruments}

In total, 23 pairs of whole air samples were collected in the tunnel, including five and 18 in summer and winter of 2003, respectively. From the results of valid samples, no statistical differences in emission factors were shown between summer and winter. We have thus combined the samples into calculation. The sampling times were chosen to cover a wide variation of vehicle usages at different time periods. One pair of samples was collected simultaneously at the tunnel entrance and exit during each sampling. The inlet sampling station was located $686 \mathrm{~m}$ inside the entrance of the south bore of Shing Mun Tunnel and the outlet sampling station was located $350 \mathrm{~m}$ upwind of the exit (Fig. 1). Ambient volatile organic canister samplers (AVOCS) (Andersen Instruments Inc. Series 97-300, Smyrna, GA, USA) were used to collect whole air samples into pre-cleaned and pre-evacuated 2-L stainless steel canisters at a flow rate of $30 \mathrm{~mL} \mathrm{~min}^{-1}$ for $1 \mathrm{~h}$ in winter and $2 \mathrm{~h}$ in summer respectively. The canisters were pressurized when sampling. The sampler was fixed on the ground level with an inlet at a height of $\sim 1.5 \mathrm{~m}$. The flow rates were checked in the field before and after each run using a calibrated flow meter. After sampling, the filled canisters were shipped to the laboratory of the University of California, Irvine for chemical analysis within two weeks of being collected.

\subsection{Traffic count analysis}

Vehicular composition and volume were determined by manual counts at the entrance of the tunnel tube at 15 -min intervals during the sampling periods. Video-recording was also taken for data validation and review purposes. The vehicle types were classified into three major categories, namely 1) LPG-fueled taxis, 2) gasoline-fueled vehicles (e.g. motorcycles, private cars), and 3) diesel-fueled vehicles (e.g. mini- and large buses, light and heavy-duty trucks). Traffic speed surveys were periodically conducted at Shing Mun Tunnel using the car chasing method. The instrumented vehicle equipped with a Darwin microwave speed sensor was driven and the tachometer sensor recorded vehicle speed on a second-by-second basis. The age and mileage distribution of vehicles were not obtained in this study.

\subsection{Chemical analyses}

All canisters were shipped to the laboratory at the University of California, Irvine (UCI) and analyzed for $\mathrm{CO}$, carbon dioxide $\left(\mathrm{CO}_{2}\right)$, methane $\left(\mathrm{CH}_{4}\right)$, and NMHCs. $\mathrm{CO}$ and $\mathrm{CO}_{2}$ analyses were carried out using a hydrogen gas methanizer upstream of a HP 5890 gas chromatography (GC) equipped with a flame ionization detector (FID) and an $3 \mathrm{~m}$ molecular sieve column. $\mathrm{CH}_{4}$ was also analyzed using an HP $5890 \mathrm{GC}$ equipped with an FID. The samples were injected into an $1 / 8^{\prime \prime}$ stainless steel $0.9 \mathrm{~m}$ column packed with $80 / 100$ mesh Spherocarb.

The analytical system used to analyze NMHCs (i.e. saturated, unsaturated, aromatic, and halogenated hydrocarbons) involved the cryogenic pre-concentration of $1520 \pm 1 \mathrm{~cm}^{3}$ (STP) of air sample in a stainless steel tube filled with glass beads $\left(1 / 8^{\prime \prime}\right.$ diameter) and immersed in liquid nitrogen $\left(-196^{\circ} \mathrm{C}\right)$. A mass flow controller with a maximum allowed flow of $500 \mathrm{~mL} \mathrm{~min}^{-1}$ controlled the trapping process. The trace gases were revolatilized using a hot water bath and then reproducibly split into five streams directed to different column-detector combinations.

Three different detectors, including quadrupole mass spectrometry detectors (MSD; for unambiguous compound identification and selected ion monitoring), FID (sensitive to hydrocarbons), and electron capture detectors (ECD; sensitive to halogenated hydrocarbon), were employed. The first column-detector combination (abbreviated as "DB5ms/MSD") was a DB-5ms column (J\&W; $60 \mathrm{~m} \times 0.25 \mathrm{~mm}$ i.d. $\times 0.5 \mu \mathrm{m}$ film thickness) output to the HP 5973 MSD. The second combination ("DB1/FID") was a DB-1 column $(\mathrm{J} \& \mathrm{~W} ; 60 \mathrm{~m} \times 0.32 \mathrm{~mm}$ i.d. $\times 1 \mu \mathrm{m}$ film thickness) output to the FID. The third combination ("PLOTDB1/FID") was a PLOT column (J\&W GS-Alumina; $30 \mathrm{~m} \times 0.53 \mathrm{~mm}$ i.d. $\times 1.5 \mu \mathrm{m}$ film thickness) connected in series to a DB-1 column $(\mathrm{J} \& \mathrm{~W} ; 5 \mathrm{~m} \times 0.53 \mathrm{~mm}$ i.d. $\times 1.5 \mu \mathrm{m}$ 
Table 1. The 1-hr average traffic composition of Shing Mun Tunnel in summer and winter in 2003.

\begin{tabular}{|c|c|c|c|c|c|c|c|c|c|c|c|}
\hline & \multicolumn{2}{|c|}{$\mathrm{LPG}^{*}$} & \multicolumn{3}{|c|}{ Gasoline } & \multicolumn{5}{|c|}{ Diesel } & \multirow[t]{2}{*}{ Total } \\
\hline & Taxis & subtotal & Motorcycles & $\begin{array}{r}\text { Private } \\
\text { Cars }\end{array}$ & subtotal & $\begin{array}{l}\text { Mini- } \\
\text { Buses }\end{array}$ & $\begin{array}{l}\text { Large } \\
\text { Buses }\end{array}$ & LDT & HDT & subtotal & \\
\hline $\begin{array}{l}\text { Summer } \\
(\%)\end{array}$ & $\begin{array}{l}233 \pm 33 \\
9.9 \pm 3.7\end{array}$ & $\begin{array}{l}233 \pm 33 \\
9.9 \pm 3.7\end{array}$ & $\begin{array}{r}42 \pm 10 \\
1.8 \pm 0.5\end{array}$ & $\begin{array}{r}918 \pm 198 \\
38.2 \pm 10.9\end{array}$ & $\begin{array}{r}961 \pm 203 \\
39.9 \pm 11\end{array}$ & $\begin{array}{l}115 \pm 43 \\
5.1 \pm 3.2\end{array}$ & $\begin{array}{l}168 \pm 73 \\
6.6 \pm 2.3\end{array}$ & $\begin{array}{l}357 \pm 179 \\
13.5 \pm 4.5\end{array}$ & $\begin{array}{r}695 \pm 467 \\
25.0 \pm 13.1\end{array}$ & $\begin{array}{r}1336 \pm 653 \\
50.1 \pm 15\end{array}$ & $2529 \pm 697$ \\
\hline $\begin{array}{l}\text { Winter } \\
(\%)\end{array}$ & $\begin{array}{r}145 \pm 60 \\
10.7 \pm 2.9\end{array}$ & $\begin{array}{r}145 \pm 60 \\
10.7 \pm 2.9\end{array}$ & $\begin{array}{r}29 \pm 18 \\
2.0 \pm 0.9\end{array}$ & $\begin{array}{l}593 \pm 205 \\
43.6 \pm 8.8\end{array}$ & $\begin{array}{l}622 \pm 220 \\
45.6 \pm 9.2\end{array}$ & $\begin{array}{r}46 \pm 13 \\
3.4 \pm 0.7\end{array}$ & $\begin{array}{l}108 \pm 48 \\
7.9 \pm 2.5\end{array}$ & $\begin{array}{l}173 \pm 103 \\
12.2 \pm 5.2\end{array}$ & $\begin{array}{l}282 \pm 164 \\
20.2 \pm 9.7\end{array}$ & $\begin{array}{r}69 \pm 241 \\
43.7 \pm 10.4\end{array}$ & $1375 \pm 428$ \\
\hline
\end{tabular}

* LPG: liquefied petroleum gas; LDT: light-duty trucks; HDT: heavy-duty trucks

film thickness) and output to the FID. The fourth combination ("Restek1701/ECD") was a RESTEK 1701 column $(60 \mathrm{~m} \times 0.25 \mathrm{~mm}$ i.d. $\times 0.50 \mu \mathrm{m}$ film thickness $)$ which was output to the ECD. The fifth combination ("DB5Restek1701/ECD”) was a DB-5 (J\&W; $30 \mathrm{~m} \times 0.25 \mathrm{~mm}$ i.d. $\times 1 \mu \mathrm{m}$ film thickness) column connected in series to a RESTEK 1701 column $(5 \mathrm{~m}, 0.25 \mathrm{~mm}$ i.d. $\times 0.5 \mu \mathrm{m}$ film thickness) and output to the ECD. The DB5ms/MS, DB1/FID, PLOT-DB1/FID, Restek1701/ECD, and DB5Restek1701/ECD combinations received 10.1, 15.1, 60.8, 7.2 , and $6.8 \%$ of the sample flow, respectively. Additional analytical details are given by Blake et al. (2001) and Colman et al. (2001). The measurement precision, detection limits and accuracy vary by compound and are quantified for each species in Colman et al. (2001). Briefly, the detection limit is $5 \mathrm{ppbv}$ for $\mathrm{CO}, 0.01-10 \mathrm{pptv}$ for halogenated hydrocarbons, and 3 pptv for other NMHCs $\left(\mathrm{CH}_{4}\right.$ is always above its detection limit). The accuracy of our measurements is $5 \%$ for $\mathrm{CO}$, $1 \%$ for $\mathrm{CH}_{4}, 2-20 \%$ for halogenated hydrocarbons, and $5 \%$ for other NMHCs. The measurement precision is 2 ppbv for $\mathrm{CO}, 2$ ppbv for $\mathrm{CH}_{4}, 1-5 \%$ for halogenated hydrocarbons, and ranges from $0.5-5 \%$ for other NMHCs.

\subsection{Emission factor}

The emission factors from tunnel measurements were calculated according to the method of Pierson (Pierson and Brachaczek, 1983; Pierson et al., 1996). The vehicular emission factor is the mass of specific pollutants produced in units of $\mathrm{mg} / \mathrm{kilometer}$, which can be determined from

$E F_{\mathrm{veh}}=\frac{\left(C_{\mathrm{out}}-C_{\mathrm{in}}\right) A U t}{N L}$

where $E F_{\text {veh }}$ is the average vehicular emission factor in mg vehicle ${ }^{-1} \mathrm{~km}^{-1}$ traveled. $C_{\text {out }}$ and $C_{\text {in }}$ represent the mass concentrations of specific pollutants at the exit and entrance in $\mathrm{mg} \mathrm{m}^{-3}$. A is the area of tunnel cross-section in $\mathrm{m}^{2}, U$ is the wind speed in $\mathrm{m} \mathrm{s}^{-1}$, and $t$ is the sampling duration (1 or $2 \mathrm{~h}$ in this study). $N$ is the total traffic number during the sampling period. $L$ is the distance between the two monitoring stations in $\mathrm{km}$. The VOC concentrations at the entrance of the tunnel were subtracted from those in the tunnel. The difference was multiplied by the tunnel air flow to determine the mass emitted during the run. This value was divided by the total vehicle distance traveling during the run to obtain the fleet mean emission rate.

\subsection{Photochemical reactivity}

It is well known that VOCs are significant precursors of $\mathrm{O}_{3}$ formation (Guo et al., 2004). Individual compound has different characteristic photochemical reactivity. In order to calculate the $\mathrm{O}_{3}$-forming potential of the vehicular emissions, the speciated emission factors for each vehicle type were multiplied by the maximum incremental reactivity (MIR) scale developed by Carter (1998). The MIR are in units of grams of $\mathrm{O}_{3}$ per gram of organic compound and therefore are simply multiplied by the emission factors (grams of organic compound per vehicle-km driven), to yield reactivityadjusted emission rates in units of $\mathrm{O}_{3}$ per vehicle-km.

\section{Results and discussion}

\subsection{Run description}

The average number of vehicles traversed the tunnel per hour during this study was 1545 , ranging from 786 to 2842 . Table 1 shows the 1-h average traffic composition of Shing Mun Tunnel in summer and winter in 2003. On average, approximately $47 \%$ of the total vehicles were diesel-fueled, $43 \%$ were gasoline, and the remaining were LPG vehicles. Dieselfueled vehicles represented the highest proportion (more than 60\%) during 11:00-13:00 and 14:00-16:00. The traffic speed for every run did not vary significantly, with most speeds recorded within the range of 60 to $70 \mathrm{~km} \mathrm{~h}^{-1}$. The average wind speed recorded in the tunnel during the sampling periods was about $4.7 \mathrm{~m} \mathrm{~s}^{-1}$.

\subsection{Concentrations of VOCs}

In this study, a total of 110 species were quantified in the samples collected at the inlet and outlet of Shing Mun 
Tunnel. These include $\mathrm{CO}, \mathrm{CO}_{2}$, carbonyl sulfide (OCS), carbon disulfide $\left(\mathrm{CS}_{2}\right), \mathrm{CH}_{4}, 40 \mathrm{C}_{2}-\mathrm{C}_{10}$ saturated hydrocarbons, $32 \mathrm{C}_{2}-\mathrm{C}_{10}$ unsaturated hydrocarbons, $21 \mathrm{C}_{6}-\mathrm{C}_{10}$ aromatic hydrocarbons and 12 halogenated hydrocarbons.

The average concentrations and standard deviations of the VOCs and their classes at the inlet and outlet of tunnel are given in Table 2. The average concentrations of the total NMHC (sum of all of measured species except $\mathrm{CO}, \mathrm{CO}_{2}$, $\mathrm{CH}_{4}$, OCS and $\mathrm{CS}_{2}$ ) at the inlet and outlet of the tunnel were 81000 pptv and 112000 pptv, respectively. Among the 105 compounds, ethene was the most abundant VOC and ethyne was the next most abundant species, followed by toluene. Interestingly, propane is the fourth most abundant gas at the tunnel inlet while $n$-butane is the fourth most abundant species at the outlet. This is thought to be the result of emissions arising from LPG vehicles (see Sect. 3.3). It has been reported that concentrations of individual VOCs in tunnels were typically 10 times higher than those of the same species measured in fresh air at the ventilation intake (Kirchstetter et al., 1996) or outside the tunnel (Mugica et al., 1998). In this study, the individual VOCs in the tunnel were generally 510 times higher than those in Hong Kong ambient air (Guo et al., 2007). Although OCS emissions make up only a small fraction of the total sulfur emitted into the atmosphere compared to $\mathrm{SO}_{2}$, its relative inertness in the troposphere, OCS is transported to the stratosphere where it is photodissociated and oxidized to $\mathrm{SO}_{2}$ and ultimately sulfate particles. Anthropogenic sources of OCS arise from the combustion of biomass and fossil fuel. Emission of OCS from vehicles is one of such example (Fried et al., 1992). The average concentrations of OCS at the inlet and outlet of the tunnel were $970 \mathrm{pptv}$ and $1200 \mathrm{pptv}$, respectively, which is higher than that of free troposphere (510 ppt) (Carroll, 1985) and similar to that in Beijing, China (1340 ppt) (Mu et al., 2002).

For both sampling locations, unsaturated hydrocarbons were the most abundant hydrocarbon group (inlet: $43 \% \pm 6 \%$; outlet: $44 \% \pm 5 \%$ ) in the samples collected in the tunnel, followed by saturated (inlet: $37 \% \pm 6 \%$; outlet: $36 \% \pm 5 \%$ ) and aromatic hydrocarbons (inlet: $16 \% \pm 2 \%$; outlet: $17 \% \pm 2 \%$ ). The weight percentages between the two locations showed no significant differences compared to their absolute concentrations. This is likely due to the fact that both of the locations were affected predominantly by vehicle exhaust.

Differences between concentrations measured at the tunnel outlet and those measured at the same time at the tunnel inlet are also shown in Table 2. The VOC composition in the tunnel air is influenced by ambient VOC concentrations. Therefore, the VOC composition obtained from the concentration difference between the two sites inside the tunnel better represents the VOC composition as compared to the results obtained from only one site. When looking at the net concentration, the five most abundant VOCs emitted by vehicles at the tunnel were, in decreasing order, ethene ethyne, $n$ butane, toluene and propane. This implies that ethene has the highest emission rate in vehicle exhaust. Ethene emissions in the tunnel contributed more than $20 \%$ of the total NMHC emissions (except $\mathrm{CO}, \mathrm{CO}_{2}, \mathrm{CH}_{4}$, OCS, and $\mathrm{CS}_{2}$ ) during most of the measurement periods. And the five most abundant species contributed over 50\% of the total NMHC emissions. Based on the net concentration, unsaturated hydrocarbons $(48 \%)$ are the most abundant, followed by saturated hydrocarbons (34\%), and aromatics hydrocarbons (17\%).

\subsection{VOC ratios}

Using the ratio of a more reactive VOC to a less reactive VOC (photochemical lifetimes (or reactivities) against hydroxyl radical $(\mathrm{OH})$, a higher ratio indicates relatively little photochemical processing of the air mass and major impact from primary emissions. On the other hand, a lower ratio is reflective of more aged VOC mixes and thus presumably that the VOCs were emitted from more distant sources (Guo et al., 2007). Comparisons of the ratios can be used to estimate the relative ages of air parcels. In this study, the ratios of ethene/ethane and $m, p$-xylene/ethylbenzene were used for comparison (Nelson and Quigley, 1983; Smyth et al., 1999; So and Wang, 2004). The average value of ethene/ethane and $m, p$-xylene/ethylbenzene in tunnel $(1.42 \pm 0.36,4.64 \pm 2.34$, $2.61 \pm 0.30)$ are higher than the ratios measured at the nearby sampling location at Tsuen Wan $(1.21 \pm 0.68,1.65 \pm 0.47)$ and other urban/rural sites in Hong Kong (Guo et al., 2007).

Ethene and ethyne are typical tracers for combustion, and thus vehicle exhaust was the likely source of these two gases (Stoeckenius et al., 2006). Tsai et al. (2006) concluded that the ethyne/ethene ratios for Hong Kong, Macau, Guangzhou and Zhuhai were $0.53 \pm 0.03,1.06 \pm 0.04,1.26 \pm 0.04$ and $1.01 \pm 0.21$, respectively. And the ethene level in the Hong Kong roadside was a factor of two higher than ethyne, whereas ethene and ethyne were close in Guangzhou, Zhuhai and Macau. The average ethyne/ethene ratio in this study is $0.45 \pm 0.07$ which is close to the previous roadside study in Hong Kong.

\subsection{Correlation of VOCs}

Correlation analysis of VOCs was carried out in order to measure the relationship between two variables. Generally, good and fair correlations $(R=0.63-0.89)$ were observed between individual VOCs and CO, except halogenated hydrocarbons, isoprene and pinenes which are emitted from different sources. Isoprene is mainly emitted from biogenic sources (e.g. vegetables) although some studies report the contribution of isoprene from vehicular exhaust (e.g. Borbon et al., 2001; Barletta et al., 2002). Here, the poor correlation between isoprene and $\mathrm{CO}$ suggests that vehicular emissions of isoprene are not significant. Our findings are consistent to other tunnel studies that isoprene was undetectable (e.g. Staehelin et al., 1998; Hwa et al., 2002). In addition, Tsai et al. (2006) has found that isoprene was not present in diesel-fueled vehicular emission in Hong Kong. These prove 
Table 2. Average concentrations of VOCs and their emission factors in summer and winter.

\begin{tabular}{|c|c|c|c|c|c|}
\hline \multirow[b]{2}{*}{ VOCs } & \multicolumn{3}{|c|}{ Concentrations (ppt) } & \multicolumn{2}{|c|}{ Emission Factor $\left(\mathrm{mg} \mathrm{veh}^{-1} \mathrm{~km}^{-1}\right)$} \\
\hline & inlet & outlet & Outlet minus inlet & mean & range \\
\hline $\mathrm{CO}_{2}$ (ppmv) & $580 \pm 50$ & $710 \pm 80$ & $130 \pm 30$ & $310000 \pm 81000$ & $180000-480000$ \\
\hline $\mathrm{CO}(\mathrm{ppbv})$ & $2800 \pm 720$ & $4100 \pm 1000$ & $1300 \pm 390$ & $1900 \pm 380$ & $1300-2600$ \\
\hline $\mathrm{CH}_{4}$ (ppmv) & $1.91 \pm 0.1$ & $1.92 \pm 0.1$ & $0.01 \pm 0.01$ & $7.2 \pm 4.8$ & $0.0-17$ \\
\hline OCS & $970 \pm 300$ & $1200 \pm 450$ & $200 \pm 440$ & $0.8 \pm 1.3$ & $0.0-5.0$ \\
\hline $\mathrm{CS}_{2}$ & $110 \pm 97$ & $190 \pm 340$ & $83 \pm 340$ & $0.4 \pm 1.3$ & $0.0-6.0$ \\
\hline \multicolumn{6}{|l|}{ alkane } \\
\hline ethane & $4400 \pm 1500$ & $5500 \pm 1800$ & $1100 \pm 550$ & $1.7 \pm 0.6$ & $0.0+2.5$ \\
\hline propane & $5800 \pm 2800$ & $8200 \pm 4000$ & $2400 \pm 1300$ & $5.7 \pm 2.5$ & $1.6-13$ \\
\hline$i$-butane & $3500 \pm 1800$ & $5300 \pm 2600$ & $1700 \pm 900$ & $5.5 \pm 2.2$ & $2.5-11$ \\
\hline$n$-butane & $5700 \pm 2500$ & $8500 \pm 3700$ & $2800 \pm 1300$ & $8.7 \pm 3.1$ & $3.9-17$ \\
\hline 2,2-dimethylbutane & $98 \pm 36$ & $130 \pm 49$ & $28 \pm 45$ & $0.2 \pm 0.2$ & $0.0-0.6$ \\
\hline 2,3-dimethylbutane & $140 \pm 64$ & $200 \pm 85$ & $61 \pm 46$ & $0.3 \pm 0.2$ & $0.0-0.7$ \\
\hline 2,2,3-trimethylbutane & $8.0 \pm 4.0$ & $12 \pm 4.0$ & $3.0 \pm 2.0$ & $0.0 \pm 0.0$ & $0.0-00$ \\
\hline$i$-pentane & $3200 \pm 1100$ & $4600 \pm 1600$ & $1500 \pm 660$ & $5.6 \pm 2.1$ & $3.1-11$ \\
\hline$n$-pentane & $980 \pm 310$ & $1400 \pm 480$ & $450 \pm 210$ & $1.7 \pm 0.6$ & $0.9-3.3$ \\
\hline 2-methylpentane & $940 \pm 330$ & $1300 \pm 470$ & $400 \pm 210$ & $1.8 \pm 0.7$ & $0.3-3.1$ \\
\hline 3-methylpentane & $670 \pm 220$ & $940 \pm 310$ & $270 \pm 140$ & $1.2 \pm 0.5$ & $0.4-2.0$ \\
\hline 3-ethylpentane & $55 \pm 100$ & $53 \pm 23$ & $-2 \pm 96$ & $0.0 \pm 0.0$ & $0.0-0.2$ \\
\hline 2,2-dimethylpentane & $24 \pm 10$ & $34 \pm 13$ & $10 \pm 5.0$ & $0.1 \pm 0.0$ & $0.0-0.1$ \\
\hline 2,3-dimethylpentane & $57 \pm 71$ & $64 \pm 51$ & $7.0 \pm 68$ & $0.1 \pm 0.1$ & $0.0-0.4$ \\
\hline 2,4-dimethylpentane & $74 \pm 28$ & $110 \pm 42$ & $34 \pm 18$ & $0.2 \pm 0.1$ & $0.1-0.3$ \\
\hline 3,3-dimethylpentane & $48 \pm 53$ & $55 \pm 22$ & $8.0 \pm 48$ & $0.1 \pm 0.0$ & $0.0-0.2$ \\
\hline 2,2,4-trimethylpentane & $350 \pm 280$ & $490 \pm 330$ & $140 \pm 250$ & $1.0 \pm 0.7$ & $0.0-2.3$ \\
\hline 2,3,4-trimethylpentane & $91 \pm 52$ & $130 \pm 88$ & $40 \pm 46$ & $0.2 \pm 0.2$ & $0.0-0.7$ \\
\hline$n$-hexane & $680 \pm 270$ & $980 \pm 410$ & $300 \pm 200$ & $1.3 \pm 0.5$ & $0.5-2.6$ \\
\hline 2-methylhexane & $390 \pm 340$ & $480 \pm 180$ & $90 \pm 290$ & $0.7 \pm 0.3$ & $0.0-1.1$ \\
\hline 3-methylhexane & $490 \pm 760$ & $490 \pm 180$ & $4 \pm 720$ & $0.8 \pm 0.3$ & $0.0-1.2$ \\
\hline 2,5-dimethylhexane & $150 \pm 180$ & $190 \pm 100$ & $41 \pm 170$ & $0.4 \pm 0.2$ & $0.0-0.9$ \\
\hline 2,4-dimethylhexane & $180 \pm 220$ & $220 \pm 110$ & $37 \pm 220$ & $0.4 \pm 0.2$ & $0.0-0.9$ \\
\hline 2,3-dimethylhexane & $74 \pm 40$ & $120 \pm 72$ & $46 \pm 39$ & $0.3 \pm 0.2$ & $0.0-0.6$ \\
\hline$n$-heptane & $430 \pm 460$ & $530 \pm 200$ & $95 \pm 390$ & $0.9 \pm 0.4$ & $0.0-2.4$ \\
\hline 2-methylheptane & $94 \pm 30$ & $150 \pm 48$ & $55 \pm 25$ & $0.3 \pm 0.1$ & $0.2-0.6$ \\
\hline 3-methylheptane & $99 \pm 31$ & $140 \pm 44$ & $39 \pm 21$ & $0.2 \pm 0.1$ & $0.0-0.4$ \\
\hline 4-methylheptane & $10 \pm 6.0$ & $17 \pm 10$ & $8.0 \pm 5.0$ & $0.1 \pm 0.0$ & $0.0-0.1$ \\
\hline 2,4-dimethylheptane & $35 \pm 21$ & $62 \pm 28$ & $27 \pm 19$ & $0.1 \pm 0.1$ & $0.0-0.2$ \\
\hline 2,5-dimethylheptane & $14 \pm 6.0$ & $25 \pm 10$ & $10 \pm 5.0$ & $0.1 \pm 0.0$ & $0.0-0.1$ \\
\hline 2,6-dimethylheptane & $28 \pm 23$ & $39 \pm 23$ & $12 \pm 21$ & $0.2 \pm 0.1$ & $0.0-0.6$ \\
\hline 3,3-dimethylheptane & $11 \pm 6.0$ & $18 \pm 9.0$ & $8.0 \pm 5.0$ & $0.1 \pm 0.0$ & $0.0-0.1$ \\
\hline 4,4-dimethylheptane & $15 \pm 7.0$ & $23 \pm 10$ & $8.0 \pm 4.0$ & $0.1 \pm 0.0$ & $0.0-0.1$ \\
\hline$n$-octane & $150 \pm 54$ & $230 \pm 76$ & $84 \pm 36$ & $0.5 \pm 0.2$ & $0.1-0.9$ \\
\hline$n$-nonane & $140 \pm 77$ & $240 \pm 107$ & $96 \pm 54$ & $0.7 \pm 0.4$ & $0.3-1.6$ \\
\hline$n$-decane & $140 \pm 100$ & $245 \pm 120$ & $103 \pm 71$ & $0.8 \pm 0.6$ & $0.0-2.4$ \\
\hline \multicolumn{6}{|l|}{ cycloalkane } \\
\hline cylopentane & $530 \pm 210$ & $810 \pm 340$ & $290 \pm 150$ & $1.0 \pm 0.4$ & $0.6-1.7$ \\
\hline methylcyclopentane & $320 \pm 110$ & $470 \pm 170$ & $150 \pm 65$ & $0.7 \pm 0.2$ & $0.4-0.9$ \\
\hline methylcyclohexane & $220 \pm 170$ & $280 \pm 110$ & $62 \pm 130$ & $0.4 \pm 0.2$ & $0.0-0.8$ \\
\hline cyclohexane & $180 \pm 93$ & $240 \pm 99$ & $62 \pm 39$ & $0.3 \pm 0.1$ & $0.0-0.6$ \\
\hline \multicolumn{6}{|l|}{ alkene } \\
\hline ethene & $16000 \pm 4200$ & $25000 \pm 7100$ & $8500 \pm 3400$ & $13 \pm 4.0$ & $0.6-21$ \\
\hline propene & $4500 \pm 1100$ & $6900 \pm 1900$ & $2400 \pm 900$ & $5.3 \pm 1.5$ & $3.2-8.3$ \\
\hline$i$-butene & $1700 \pm 510$ & $2600 \pm 850$ & $840 \pm 560$ & $2.5 \pm 1.3$ & $0.0-4.7$ \\
\hline$c i s$-2-butene & $290 \pm 99$ & $450 \pm 160$ & $160 \pm 62$ & $0.5 \pm 0.1$ & $0.3-0.8$ \\
\hline trans-2-butene & $400 \pm 130$ & $620 \pm 210$ & $220 \pm 87$ & $0.6 \pm 0.2$ & $0.5-1.1$ \\
\hline 1-butene & $940 \pm 250$ & $1500 \pm 380$ & $530 \pm 210$ & $1.6 \pm 0.6$ & $0.4-2.6$ \\
\hline 1,3-butadiene & $410 \pm 390$ & $360 \pm 340$ & $-46 \pm 360$ & $0.3 \pm 0.6$ & $0.0-2.3$ \\
\hline 2-methyl-1-butene & $210 \pm 82$ & $330 \pm 130$ & $120 \pm 53$ & $0.5 \pm 0.2$ & $0.2-0.9$ \\
\hline 2-methyl-2-butene & $260 \pm 180$ & $400 \pm 240$ & $140 \pm 130$ & $0.6 \pm 0.4$ & $0.0-1.7$ \\
\hline 3-methyl-1-butene & $110 \pm 32$ & $170 \pm 52$ & $61 \pm 22$ & $0.2 \pm 0.1$ & $0.1-0.3$ \\
\hline trans-2-pentene & $270 \pm 100$ & $440 \pm 170$ & $160 \pm 71$ & $0.6 \pm 0.2$ & $0.3-1.0$ \\
\hline 1-pentene & $460 \pm 340$ & $950 \pm 750$ & $500 \pm 550$ & $1.9 \pm 2.1$ & $0.4-9.2$ \\
\hline
\end{tabular}


Table 2. Continued.

\begin{tabular}{|c|c|c|c|c|c|}
\hline \multirow[b]{2}{*}{ VOCs } & \multicolumn{3}{|c|}{ Concentrations (ppt) } & \multicolumn{2}{|c|}{ Emission Factor $\left(\mathrm{mg} \mathrm{veh}^{-1} \mathrm{~km}^{-1}\right)$} \\
\hline & inlet & outlet & Outlet minus inlet & mean & range \\
\hline 2-methyl-1-pentene & $260 \pm 150$ & $460 \pm 280$ & $200 \pm 130$ & $0.9 \pm 0.5$ & $0.1-1.9$ \\
\hline 3-methyl-1-pentene & $69 \pm 31$ & $99 \pm 31$ & $30 \pm 32$ & $0.2 \pm 0.1$ & $0.0-0.3$ \\
\hline 4-methyl-1-pentene & $93 \pm 31$ & $170 \pm 57$ & $73 \pm 38$ & $0.3 \pm 0.1$ & $0.2-0.6$ \\
\hline 2-methyl-2-pentene & $78 \pm 43$ & $120 \pm 60$ & $43 \pm 37$ & $0.2 \pm 0.2$ & $0.0-0.7$ \\
\hline cis-3-methyl-2-pentene & $67 \pm 37$ & $100 \pm 51$ & $38 \pm 31$ & $0.2 \pm 0.1$ & $0.0-0.6$ \\
\hline trans-3-methyl-2-pentene & $42 \pm 26$ & $63 \pm 35$ & $21 \pm 24$ & $0.1 \pm 0.1$ & $0.0-0.4$ \\
\hline 1-hexene & $130 \pm 56$ & $210 \pm 110$ & $86 \pm 72$ & $0.4 \pm 0.3$ & $0.0-1.3$ \\
\hline cis-2-hexene & $44 \pm 17$ & $74 \pm 29$ & $30 \pm 14$ & $0.1 \pm 0.0$ & $0.1-0.2$ \\
\hline trans-2-hexene & $81 \pm 29$ & $140 \pm 49$ & $55 \pm 24$ & $0.2 \pm 0.1$ & $0.1-0.4$ \\
\hline cis-3-hexene & $21 \pm 6.0$ & $27 \pm 10$ & $6.0 \pm 12$ & $0.0 \pm 0.0$ & $0.0-0.1$ \\
\hline trans-3-hexene & $34 \pm 14$ & $54 \pm 23$ & $20 \pm 11$ & $0.1 \pm 0.0$ & $0.0-0.2$ \\
\hline limonene & $9.0 \pm 5.0$ & $11 \pm 9.0$ & $5.0 \pm 11$ & $0.0 \pm 0.1$ & $0.0-0.4$ \\
\hline$\alpha$-pinene & $12 \pm 7.0$ & $10 \pm 7.0$ & $1.0 \pm 5.0$ & $0.0 \pm 0.0$ & $0.0-0.1$ \\
\hline$\beta$-pinene & $6.0 \pm 3.0$ & $5.0 \pm 2.0$ & $0.0 \pm 2.0$ & $0.0 \pm 0.0$ & $0.0-0.0$ \\
\hline isoprene & $160 \pm 340$ & $56 \pm 63$ & $-110 \pm 360$ & $0.0 \pm 0.0$ & $0.0-1.0$ \\
\hline \multicolumn{6}{|l|}{ alkyne } \\
\hline ethyne & $7400 \pm 1800$ & $10000 \pm 2600$ & $3000 \pm 1300$ & $4.0 \pm 1.3$ & $1.6-7.0$ \\
\hline propyne & $320 \pm 74$ & $480 \pm 130$ & $160 \pm 67$ & $0.3 \pm 0.1$ & $0.2-0.5$ \\
\hline 2-butyne & $5.0 \pm 2.0$ & $8.0 \pm 2.0$ & $42 \pm 186$ & $0.0 \pm 0.0$ & $0.0-0.0$ \\
\hline 1-butyne & $12 \pm 5.0$ & $21 \pm 7.0$ & $9.0 \pm 4.0$ & $0.0 \pm 0.0$ & $0.0-0.1$ \\
\hline \multicolumn{6}{|l|}{ aromatic hydrocarbon } \\
\hline benzene & $2500 \pm 620$ & $3500 \pm 920$ & $1100 \pm 380$ & $4.5 \pm 0.9$ & $2.5-6.0$ \\
\hline ethylbenzene & $590 \pm 210$ & $820 \pm 270$ & $240 \pm 110$ & $1.3 \pm 0.4$ & $0.7-2.0$ \\
\hline 1,4-diethylbenzene & $69 \pm 56$ & $150 \pm 72$ & $84 \pm 75$ & $0.6 \pm 0.4$ & $0.0-1.3$ \\
\hline 1,3-diethylbenzene & $31 \pm 15$ & $53 \pm 22$ & $25 \pm 27$ & $0.2 \pm 0.2$ & $0.0-0.6$ \\
\hline 1,2-diethylbenzene & $17 \pm 9$ & $25 \pm 13$ & $10 \pm 11$ & $0.1 \pm 0.1$ & $0.0-0.3$ \\
\hline 1,2,3-trimethylbenzene & $280 \pm 150$ & $480 \pm 190$ & $250 \pm 340$ & $1.4 \pm 1.1$ & $0.0-3.8$ \\
\hline 1,2,4-trimethylbenzene & $720 \pm 400$ & $1200 \pm 460$ & $480 \pm 460$ & $3.0 \pm 2.4$ & $0.0-8.3$ \\
\hline 1,3,5-trimethylbenzene & $180 \pm 70$ & $300 \pm 92$ & $120 \pm 72$ & $0.8 \pm 0.4$ & $0.3-1.8$ \\
\hline isopropylbenzene & $33 \pm 10$ & $48 \pm 17$ & $15 \pm 13$ & $0.1 \pm 0.1$ & $0.0-0.2$ \\
\hline$n$-propylbenzene & $120 \pm 41$ & $200 \pm 63$ & $74 \pm 43$ & $0.5 \pm 0.2$ & $0.2-0.9$ \\
\hline isobutylbenzene & $7.0 \pm 3.0$ & $10 \pm 5.0$ & $5.0 \pm 4.0$ & $0.0 \pm 0.0$ & $0.0-0.1$ \\
\hline sec-butylbenzene & $20 \pm 11$ & $31 \pm 15$ & $14 \pm 11$ & $0.1 \pm 0.1$ & $0.0-0.3$ \\
\hline$n$-butylbenzene & $23 \pm 10$ & $35 \pm 16$ & $15 \pm 19$ & $0.1 \pm 0.1$ & $0.0-0.4$ \\
\hline toluene & $6100 \pm 2000$ & $8700 \pm 2800$ & $2500 \pm 1200$ & $12 \pm 3.9$ & $6.9-23$ \\
\hline 2-ethyltoluene & $210 \pm 99$ & $380 \pm 140$ & $170 \pm 140$ & $1.0 \pm 0.7$ & $0.0-2.5$ \\
\hline 3-ethyltoluene & $320 \pm 130$ & $530 \pm 200$ & $210 \pm 180$ & $1.4 \pm 0.9$ & $0.0-3.7$ \\
\hline 4-ethyltoluene & $130 \pm 61$ & $270 \pm 230$ & $130 \pm 210$ & $0.7 \pm 0.8$ & $0.0-2.8$ \\
\hline isopropyltoluene & $6.0 \pm 3.0$ & $7.0 \pm 3.0$ & $2.0 \pm 5.0$ & $0.0 \pm 0.0$ & $0.0-0.1$ \\
\hline$o$-xylene & $640 \pm 180$ & $940 \pm 310$ & $290 \pm 160$ & $1.6 \pm 0.6$ & $0.7-2.8$ \\
\hline$m$-xylene & $1000 \pm 320$ & $1500 \pm 500$ & $470 \pm 230$ & $2.6 \pm 0.9$ & $1.3-4.6$ \\
\hline$p$-xylene & $450 \pm 140$ & $660 \pm 210$ & $200 \pm 96$ & $1.1 \pm 0.4$ & $0.6-2.0$ \\
\hline \multicolumn{6}{|l|}{ halogenated hydrocarbon } \\
\hline $\mathrm{CH}_{3} \mathrm{Cl}$ & $800 \pm 140$ & $790 \pm 140$ & $-11 \pm 87$ & $0.0 \pm 0.0$ & $0.0-0.7$ \\
\hline $\mathrm{CH}_{2} \mathrm{Cl}_{2}$ & $180 \pm 140$ & $190 \pm 140$ & $9.0 \pm 46$ & $0.1 \pm 0.1$ & $0.0-0.4$ \\
\hline $\mathrm{CHCl}_{3}$ & $28 \pm 19$ & $28 \pm 13$ & $0.0 \pm 4.0$ & $0.0 \pm 0.0$ & $0.0-0.1$ \\
\hline $\mathrm{CCl}_{4}$ & $99 \pm 4.0$ & $100 \pm 3$ & $0.0 \pm 3.0$ & $0.0 \pm 0.0$ & $0.0-0.1$ \\
\hline $\mathrm{CH}_{3} \mathrm{Br}$ & $50 \pm 120$ & $72 \pm 190$ & $22 \pm 78$ & $0.1 \pm 0.5$ & $0.0-2.3$ \\
\hline $\mathrm{CH}_{2} \mathrm{Br}_{2}$ & $1.4 \pm 0.2$ & $1.2 \pm 0.2$ & $-0.1 \pm 0.1$ & $0.0 \pm 0.0$ & $0.0-0.0$ \\
\hline $\mathrm{CHBr}_{3}$ & $4.2 \pm 2.1$ & $4.6 \pm 1.9$ & $0.4 \pm 1.2$ & $0.0 \pm 0.0$ & $0.0-0.1$ \\
\hline $\mathrm{CHCl}_{3}$ & $28 \pm 19$ & $28 \pm 13$ & $0.0 \pm 4.0$ & $0.0 \pm 0.0$ & $0.0-0.1$ \\
\hline 1,2-dichloroethene & $18 \pm 14$ & $20 \pm 15$ & $2.0 \pm 4.0$ & $0.0 \pm 0.0$ & $0.0-0.1$ \\
\hline $\mathrm{C}_{2} \mathrm{HCl}_{3}$ & $50 \pm 78$ & $51 \pm 81$ & $2.0 \pm 9.0$ & $0.0 \pm 0.0$ & $0.0-0.2$ \\
\hline $\mathrm{C}_{2} \mathrm{Cl}_{4}$ & $96 \pm 91$ & $95 \pm 85$ & $-1 \pm 13$ & $0.0 \pm 0.0$ & $0.0-0.2$ \\
\hline $\mathrm{H}-1211\left(\mathrm{CBrClF}_{2}\right)$ & $7.0 \pm 4.0$ & $8.0 \pm 5.0$ & $0.0 \pm 1.0$ & $0.0 \pm 0.0$ & $0.0-0.1$ \\
\hline saturated $^{\mathrm{a}}$ & $31000 \pm 11000$ & $43000 \pm 15000$ & $13000 \pm 6400$ & $23-66$ & \\
\hline unsaturated $^{\mathrm{b}}$ & $35000 \pm 8400$ & $52000 \pm 14000$ & $17000 \pm 6400$ & $35 \pm 9.4$ & $16-56$ \\
\hline aromatic hydrocarbon & $13000 \pm 3800$ & $20000 \pm 6100$ & $6400 \pm 3200$ & $33 \pm 11$ & $18-50$ \\
\hline halogenated hydrocarbon & $1400 \pm 400$ & $1400 \pm 380$ & $26 \pm 130$ & $0.5 \pm 0.5$ & $0.0-2.4$ \\
\hline total NMHCs & $81000 \pm 21000$ & $120000 \pm 32000$ & $37000 \pm 14000$ & $115 \pm 26$ & $67-150$ \\
\hline
\end{tabular}

\footnotetext{
a Saturated hydrocarbon includes alkane and cycloalkane.
}

b Unsaturated hydrocarbon includes alkene and alkyne. 
Table 3. Correlation of emission factors of selected VOCs with the change of the fractions of vehicle types.

\begin{tabular}{|c|c|c|}
\hline VOCs & Linear Regression $^{a}$ & $R$ \\
\hline \multicolumn{3}{|l|}{ LPG-fueled vehicles } \\
\hline propane & propane $=1.53+35.1 \chi_{L}$ & 0.58 \\
\hline$i$-butane & $i$-butane $=1.87+32.2 \chi_{L}$ & 0.55 \\
\hline$n$-butane & $n$-butane $=3.61+46.0 \chi_{L}$ & 0.54 \\
\hline ethane & ethane $=1.15+6.50 \chi_{L}$ & 0.54 \\
\hline \multicolumn{3}{|l|}{ gasoline-fueled vehicles } \\
\hline toluene & toluene $=2.78+23.00 \chi g$ & 0.68 \\
\hline ethylbenzene & ethylbenzene $=0.03+2.97 \chi_{g}$ & 0.68 \\
\hline$m$-xylene & $m$-xylene $=0.137+5.58 \chi_{g}$ & 0.62 \\
\hline 3-methylpentane & 3-methylpentane $=0.21+2.55 \chi_{g}$ & 0.62 \\
\hline$i$-butene & $i$-butene $=0.18+6.15 \chi_{g}$ & 0.60 \\
\hline$p$-xylene & $p$-xylene $=0.235+2.02 \chi g$ & 0.57 \\
\hline$o$-xylene & $o$-xylene $=0.20+3.25 \chi g$ & 0.56 \\
\hline 2-methylpentane & 2-methylpentane $=0.27+3.70 \chi g$ & 0.55 \\
\hline$i$-pentane & $i$-pentane $=1.06+11.3 \chi g$ & 0.53 \\
\hline$n$-pentane & $n$-pentane $=0.19+3.45 \chi g$ & 0.53 \\
\hline ethane & ethane $=0.87+2.22 \chi_{g}$ & 0.52 \\
\hline 3-ethyltoluene & 3-ethyltoluene $=0.26+3.77 \chi g$ & 0.45 \\
\hline 1,2,3-triethylbenzene & $1,2,4$-trimethylbenzene $=-0.83+5.47 \chi_{g}$ & 0.45 \\
\hline$n$-hexane & $n$-hexane $=0.36+1.92 \chi_{g}$ & 0.44 \\
\hline 1,2,4-trimethylbenzene & 1,2,4-trimethylbenzene $=-0.78+8.81 \chi_{g}$ & 0.40 \\
\hline \multicolumn{3}{|l|}{ diesel-fueled vehicles } \\
\hline ethene & ethene $=3.98+21.7 \chi_{d}$ & 0.74 \\
\hline 1-pentene & 1 -pentene $=-3.28+12.0 \chi_{d}$ & 0.59 \\
\hline 1-butene & 1-butene $=0.48+2.58 \chi_{d}$ & 0.53 \\
\hline propene & propene $=2.56+6.69 \chi_{d}$ & 0.49 \\
\hline ethyne & ethyne $=2.36+4.47 \chi_{d}$ & 0.46 \\
\hline benzene & benzene $=3.00+3.21 \chi_{d}$ & 0.44 \\
\hline
\end{tabular}

${ }^{\mathrm{a}} \chi_{L}=$ fractions of LPG-fueled vehicles; $\chi_{g}=$ fractions of gasoline-fueled vehicles; $\chi_{d}=$ fractions of diesel-fueled vehicles.

that the formation of isoprene from vehicular emission is uncertain. The variations of fuel types and vehicular engines used in different countries are possible explanation.

Moreover, strong and fair correlations were determined from marker species of fuel vapor (LPG, gasoline, and diesel). Propane, $n$-butane and $i$-butane are the major constituents of LPG in Hong Kong (Tsai et al., 2006) and strong correlations were found ( $R=0.95-0.98)$ among the species which indicated that unburned LPG was emitted to the tunnel atmosphere. $n$-pentane, $i$-pentane, 2,3dimethylbutane, 2-methylpentane and toluene are the most abundant VOCs from the exhaust of gasoline-fueled vehicle and the evaporative loss from gasoline vapor (Tsai et al., 2006). Strong correlations $(R=0.82-0.96)$ of these species indicated the importance of emissions from gasoline-fueled vehicles. Moreover, good correlations $(R=0.54-0.95)$ were observed among diesel-fueled species ( $n$-nonane, $n$-decane and 1,2,4-trimethylbenzene) (Tsai et al., 2006).

\subsection{Emission factors of VOCs}

The average emission factors of VOCs are given in Table 2. (Zero emission factors for some VOCs results from $C_{\text {outlet }}$ begins less than or the same as $C_{\text {inlet }}$ ). The total measured VOC emission factors ranged from $67.2 \mathrm{mg} \mathrm{veh}^{-1} \mathrm{~km}^{-1}$ to $148 \mathrm{mg} \mathrm{veh}^{-1} \mathrm{~km}^{-1}$. The average emission factor was $115 \mathrm{mg} \mathrm{veh}^{-1} \mathrm{~km}^{-1}$. The five most abundant VOC species in vehicle emissions were, in decreasing order, ethene $\left(12.6 \pm 4.3 \mathrm{mg} \mathrm{veh}^{-1} \mathrm{~km}^{-1}\right)$, toluene $\left(12.1 \pm 3.9 \mathrm{mg} \mathrm{veh}^{-1} \mathrm{~km}^{-1}\right), n$-butane $\left(8.7 \pm 3.1 \mathrm{mg} \mathrm{veh}{ }^{-1}\right.$ $\left.\mathrm{km}^{-1}\right)$, propane $\left(5.7 \pm 2.5 \mathrm{mg} \mathrm{veh}{ }^{-1} \mathrm{~km}^{-1}\right)$ and $i$-pentane $\left(5.6 \pm 2.1 \mathrm{mg} \mathrm{veh}^{-1} \mathrm{~km}^{-1}\right)$ (Table 2$)$. The ethene emissions in tunnel contributed $>11 \%$ of the total NMHC emissions (except $\mathrm{CO}, \mathrm{CO}_{2}, \mathrm{CH}_{4}$, OCS, and $\mathrm{CS}_{2}$ ). The five most abundant species contributed over $38 \%$ of the total NMHC emissions. Emission factors measured in this study are for warm engine moving vehicles. Higher emissions of VOCs may be observed in an urban setting where more vehicles are in cold start and off-cycle conditions. The emission factor of 
Table 4. Emission factors of select VOC compounds for LPG, gasoline and diesel-fueled vehicles from regression of experimental data.

\begin{tabular}{|c|c|c|c|c|c|c|}
\hline & LPG & & gasoline & & diesel & \\
\hline VOCs & $\begin{array}{r}\text { Emission } \\
\text { Factor } \\
\left(\mathrm{mg} \mathrm{veh}^{-1} \mathrm{~km}^{-1}\right)\end{array}$ & $R$ & $\begin{array}{r}\text { Emission } \\
\text { Factor } \\
\left(\mathrm{mg} \mathrm{veh}^{-1} \mathrm{~km}^{-1}\right)\end{array}$ & $R$ & $\begin{array}{r}\text { Emission } \\
\text { Factor } \\
\left(\mathrm{mg} \mathrm{veh}^{-1} \mathrm{~km}^{-1}\right)\end{array}$ & $R$ \\
\hline ethene & & -0.47 & $0.21 \pm 3.06$ & -0.71 & $25.7 \pm 2.62$ & 0.74 \\
\hline toluene & & 0.30 & $25.7 \pm 3.56$ & 0.68 & $2.89 \pm 2.84$ & -0.65 \\
\hline$n$-butane & $49.6 \pm 15.1$ & 0.54 & & 0.32 & $3.89 \pm 2.41$ & -0.40 \\
\hline propane & $36.6 \pm 10.1$ & 0.58 & & 0.38 & $1.50 \pm 1.63$ & -0.46 \\
\hline$i$-pentane & & 0.39 & $12.3 \pm 2.60$ & 0.53 & $0.89 \pm 1.96$ & -0.54 \\
\hline$i$-butane & $34.1 \pm 10.5$ & 0.55 & & 0.33 & $1.99 \pm 1.67$ & -0.41 \\
\hline propene & & -0.22 & $1.23 \pm 1.78$ & -0.51 & $9.34 \pm 1.66$ & 0.49 \\
\hline benzene & & -0.17 & $2.21 \pm 1.03$ & -0.46 & $6.21 \pm 0.87$ & 0.44 \\
\hline ethyne & & -0.34 & $1.67 \pm 1.32$ & -0.43 & $6.84 \pm 1.16$ & 0.46 \\
\hline 1,2,4-trimethylbenzene & & 0.35 & $8.03 \pm 2.65$ & 0.40 & & -0.42 \\
\hline$m$-xylene & & 0.35 & $5.72 \pm 0.97$ & 0.62 & $0.21 \pm 0.75$ & -0.60 \\
\hline$i$-butene & & 0.29 & $6.33 \pm 1.11$ & 0.60 & $0.13 \pm 0.93$ & -0.58 \\
\hline 1-pentene & & -0.31 & & -0.59 & $8.76 \pm 2.17$ & 0.59 \\
\hline 2-methylpentane & & 0.30 & $3.97 \pm 0.75$ & 0.55 & $0.27 \pm 0.60$ & -0.53 \\
\hline ethane & $7.65 \pm 2.14$ & 0.54 & $3.08 \pm 0.49$ & 0.52 & $0.69 \pm 0.38$ & -0.59 \\
\hline$n$-pentane & & 0.38 & $3.64 \pm 0.75$ & 0.53 & $0.12 \pm 0.57$ & -0.55 \\
\hline 1-butene & & -0.21 & & -0.57 & $3.06 \pm 0.53$ & 0.53 \\
\hline$o$-xylene & & 0.39 & $3.46 \pm 0.68$ & 0.56 & $0.21 \pm 0.51$ & -0.55 \\
\hline 1,2,3-trimethylbenzene & & 0.28 & $4.64 \pm 1.59$ & 0.45 & & -0.44 \\
\hline 3-ethyltoluene & & 0.03 & $3.51 \pm 1.00$ & 0.45 & & -0.39 \\
\hline$n$-hexane & & -0.03 & $2.28 \pm 0.52$ & 0.44 & & -0.37 \\
\hline ethylbenzene & & 0.37 & $3.00 \pm 0.43$ & 0.68 & $0.07 \pm 0.34$ & -0.66 \\
\hline 3-methylpentane & & 0.38 & $2.76 \pm 0.44$ & 0.62 & $0.17 \pm 0.36$ & -0.61 \\
\hline$p$-xylene & & 0.32 & $2.26 \pm 0.40$ & 0.57 & $0.26 \pm 0.31$ & -0.55 \\
\hline
\end{tabular}

OCS ranged from 0.05 to $3.2 \mathrm{mg} \mathrm{veh}^{-1} \mathrm{~km}^{-1}$. The average emission factor was $0.8 \mathrm{mg} \mathrm{veh}{ }^{-1} \mathrm{~km}^{-1}$ which is higher than previous study done by chassis dynamometer (Fried et al., 1992).

Linear regression analysis was carried out to determine the variations of emission factors of individual VOC with the change of the fractions of vehicle types (LPG-fueled taxis, gasoline-fueled vehicles, and diesel-fueled vehicles) in tunnel. The equations of linear regression and correlation coefficient of selected VOCs (total emission factor $>1 \mathrm{mg} \mathrm{veh}^{-1} \mathrm{~km}^{-1}$ and $R>0.4$ ) are presented in Table 3 . High propane, $i$-butane, $n$-butane and ethane emissions were found to be associated with a high proportion of LPG-fueled taxis. Fair correlations were observed between propane, $i$ butane, $n$-butane and ethane with the fractions of LPG-fueled taxis $(R=0.54-0.58)$. Moreover, fair correlations were determined between marker species with fractions of gasolinefueled and diesel-fueled vehicles (Table 3).

The emissions of LPG-, gasoline-, and diesel-fueled vehicles can be differentiated from the regression equations of emissions of emission factors of individual VOC with the change of the fractions of vehicle types (under the conditions of total emission factor $>1 \mathrm{mg} \mathrm{vhe}^{-1} \mathrm{~km}^{-1}$ and $R> \pm 0.4$ ).
The uncertainty estimate for the emission factor was determined from the regression statistics. The emission factors of selected VOCs from Shing Mun Tunnel are presented in Table 4. The correlation coefficient $(R)$ for the plot of the experimental emission factors was also shown. The three VOCs with the largest LPG-fueled emission factors were, in decreasing order, $n$-butane, propane, and $i$-butane. In addition, the three most abundant VOCs in gasoline- and dieselfueled vehicles emission were, in decreasing order, toluene, i-pentane, 1,2,4-trimethylbenzene, and ethane, propene, 1pentene, respectively.

\subsection{Effect of fuel evaporative loss in the tunnel atmosphere}

Figure 2 shows the selected VOC distribution measured in Shing Mun Tunnel and was compared with the compositions of gasoline vapor and LPG collected in 2003 (in weight percent composition) (Tsai, 2007). The individual weight percentage was calculated by normalizing individual weight concentration $\left(\mathrm{mg} \mathrm{m}^{-3}\right)$ to total weight concentration. As diesels samples consisted mainly of heavy $\left(\mathrm{C}_{8}-\mathrm{C}_{10}\right)$ hydrocarbons (such as $n$-decane), these compounds have low vapor 


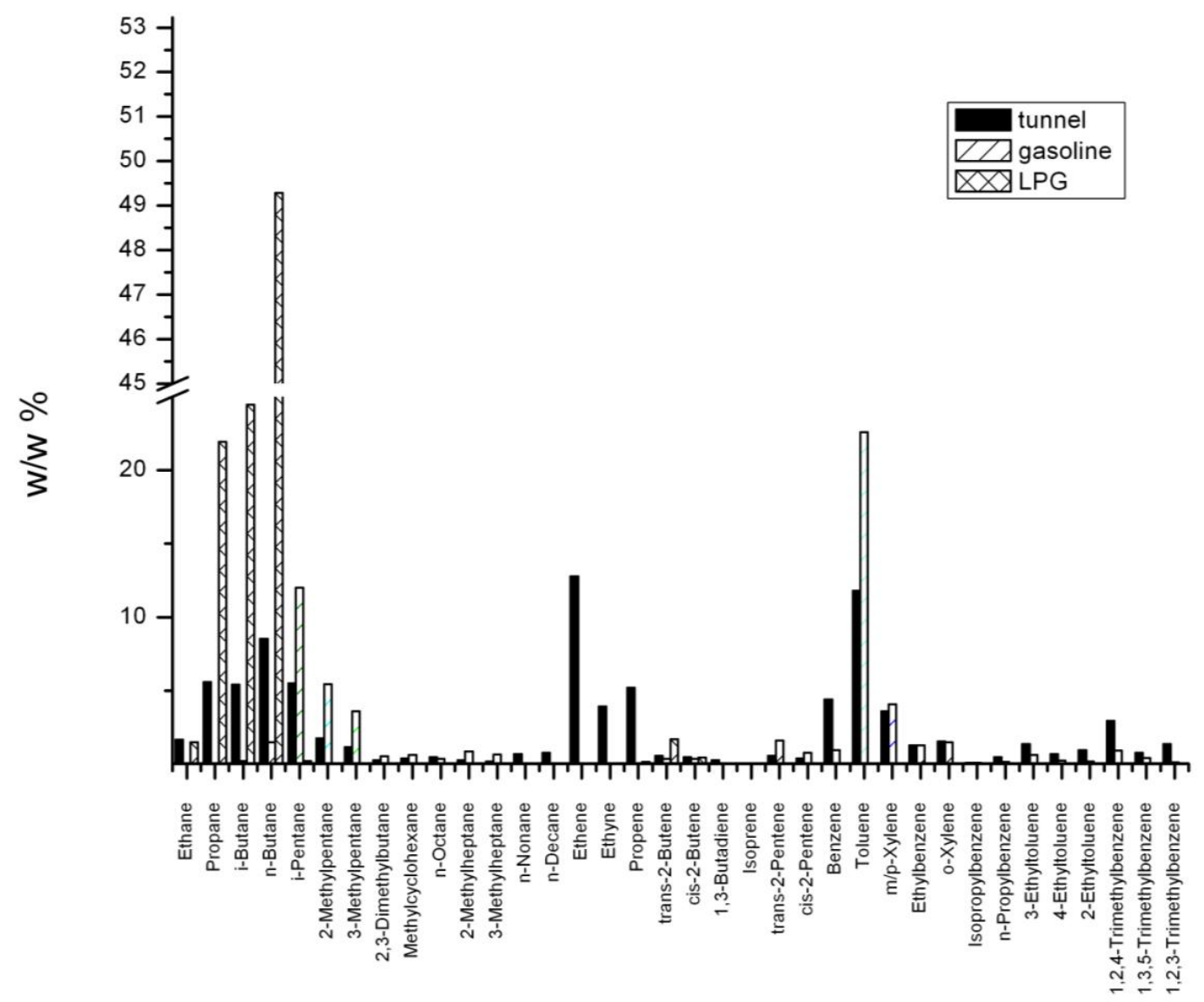

Fig. 2. Average VOC distributions (presented in w/w\%) for gasoline vapor, LPG and Shing Mun Tunnel samples.

pressures and thus do not quickly evaporate into the atmosphere (Tsai et al., 2006), suggesting that evaporative loss from diesel to the tunnel atmosphere was insignificant compared with the light species from gasoline and LPG. It is clear that there are several VOCs that were abundant in the tunnel but not the gasoline vapors or LPG samples, namely ethene, ethyne, and propene. These species are typical tracers for fossil fuel combustion.

Propane, $i$-butane and $n$-butane are tracers for LPG, the propane/( $n$ - $+i$-butanes) ratio of LPG was 0.30 , and the ratio of tunnel sample ranged from 0.24 to 0.51 . The similar propane/( $n-+i$-butanes) ratio obtained in Shing Mun Tunnel and the LPG samples indicates that the propane and butanes measured in the tunnel resulted from running evaporative losses of LPG. These findings are consistent with the previous study (Tsai et al., 2006). Moreover, the abundances of toluene and $i$-pentane were high in Shing Mun Tunnel. These two gases are tracers of gasoline evaporation (Tsai et al., 2006) The high concentrations observed in tunnel indicated the evaporative loss from gasoline-fueled vehicles is one of the sources for toluene and $i$-pentane. Gasoline evaporation was found to contribute $14 \%$ of total VOC emission in Hong Kong in 2001-2002 (Guo et al., 2006).

\subsection{Reactivity with respect to ozone formation}

VOCs are precursors of $\mathrm{O}_{3}$ formation. To assess the relative importance of VOCs from vehicular emissions in Hong Kong, we apply the MIR to evaluate the contributions of individual VOCs to $\mathrm{O}_{3}$ production (Carter, 1994 and 2003). The top ten reactivities with respect to $\mathrm{O}_{3}$ formation of emissions are presented in Table 5. The largest contributors to $\mathrm{O}_{3}$ production in Shing Mun Tunnel were ethene $\left(126 \mathrm{mg} \mathrm{O}_{3} \mathrm{veh}^{-1} \mathrm{~km}^{-1}\right)$, propene $\left(66 \mathrm{mg} \mathrm{O}_{3} \mathrm{veh}^{-1} \mathrm{~km}^{-1}\right)$, and toluene $\left(51 \mathrm{mg} \mathrm{O}_{3} \mathrm{veh}^{-1} \mathrm{~km}^{-1}\right)$. Ethene emissions were responsible for $23 \%$ of the measured VOC reactivity for vehicular emissions, followed by propene and toluene at $12 \%$ and $9.0 \%$. In the same tunnel, the emission factors of carbonyl compounds were determined (Ho et al., 2006). Individual species are grouped into saturated hydrocarbons, unsaturated hydrocarbons, aromatic hydrocarbons and halogenated hydrocarbons to determine the group lump-sum $\mathrm{O}_{3}$ formation potential. The unsaturated hydrocarbons contribute $32 \%$ of potential $\mathrm{O}_{3}$ formation which is the most among the species. The total $\mathrm{O}_{3}$ formation potential is $568 \mathrm{mg} \mathrm{O}_{3} \mathrm{~km}^{-1} \mathrm{veh}^{-1}$. On the basis of $100 \mathrm{~g}$ VOCs emitted, $\mathrm{O}_{3}$ formation is $494 \mathrm{~g}$ (average emission rate of total 
Table 5. Top 10 VOCs for ozone-forming potential of LPG, gasoline and diesel-fueled vehicles emissions estimated at Shing Mun Tunnel.

\begin{tabular}{|c|c|c|c|c|c|c|c|}
\hline VOCs & $\begin{array}{r}\text { Ozone- } \\
\text { formation } \\
{\text { potential }{ }^{\mathrm{a}} \text { for }} \\
\text { mixed vehicle }\end{array}$ & VOCs & $\begin{array}{r}\text { Ozone- } \\
\text { formation } \\
\text { potential }^{\mathrm{a}} \text { for } \\
\text { mixed vehicle }\end{array}$ & VOCs & $\begin{array}{r}\text { Ozone- } \\
\text { formation } \\
\text { potential }^{\mathrm{a}} \text { for } \\
\text { mixed vehicle }\end{array}$ & VOCs & $\begin{array}{r}\text { Ozone- } \\
\text { formation } \\
\text { potential }^{\mathrm{a}} \text { for } \\
\text { mixed vehicle }\end{array}$ \\
\hline ethene & 125.9 & $n$-butane & 65.4 & toluene & 101.9 & ethene & 232.7 \\
\hline propene & 65.9 & $i$-butane & 45.7 & $m$-xylene & 60.7 & propene & 108.1 \\
\hline toluene & 50.7 & propane & 20.5 & $1,2,4-\mathrm{TMB}$ & 57.7 & 1-pentene & 67.7 \\
\hline$m$-xylene & 28.7 & ethane & 2.37 & 1,2,3-ТMB & 52.2 & 1-butene & 31.3 \\
\hline $1,2,4-\mathrm{TMB}^{\mathrm{b}}$ & 22.6 & & & $i$-butene & 39.9 & toluene & 11.5 \\
\hline 1-butene & 17.5 & & & 3-ethyltoluene & 32.9 & ethyne & 8.48 \\
\hline$i$-butene & 17.2 & & & $o$-xylene & 25.9 & $n$-butane & 5.13 \\
\hline 1,2,3-ТMB & 16.4 & & & $i$-pentane & 20.6 & benzene & 5.03 \\
\hline$n$-butane & 12.6 & & & propenep & 14.2 & $i$-butane & 2.67 \\
\hline$o$-xylene & 12.4 & & & $p$-xylene & 9.58 & $m$-xylene & 2.23 \\
\hline
\end{tabular}

a Ozone formation potential is calculated as emission factor of VOCs $\left(\mathrm{mg} \mathrm{veh}{ }^{-1} \mathrm{~km}^{-1}\right)$ multiplied by maximum incremental reactivity (MIR) coefficient (dimensionless, gram of ozone produced per additional gram of VOCs).

$\mathrm{b}$ TMB represents trimethylbenzene.

VOCs is $115 \mathrm{mg} \mathrm{veh}^{-1} \mathrm{~km}^{-1}$ ) which is similar to the results of Taipei tunnel, of $427 \mathrm{~g}$ (Hwa et al., 2002). Using the same calculation method, the top ten $\mathrm{O}_{3}$-forming potential of diesel-, LPG-, gasoline-fueled vehicles emission are determined. The largest contributors to $\mathrm{O}_{3}$ production in Shing Mun Tunnel for LPG-, gasoline-, and diesel-fueled vehicles were $n$-butane, toluene, and ethene, respectively.

\subsubsection{Comparison of tunnel results with other studies}

Of studies that identified VOCs from vehicular emissions in tunnels, few have included calculations of emission factors. A summary of literature data for selected VOCs are shown in Table 6. Generally, the emission factors from our study are similar or lower than other tunnel studies. The three largest abundant emission factors of VOCs in a Taipei Tunnel are toluene, ethene and 1,2,4-trimethylbenzene $\left(29.0 \pm 4.95,26.2 \pm 4.89\right.$ and $14.3 \pm 2.94 \mathrm{mg} \mathrm{km}^{-1} \mathrm{veh}^{-1}$, respectively), which are 2 to 5 times higher than our study (Hwa et al., 2002). Characteristic VOCs emissions may directly reflect the specific formula of gasoline or diesel fuel used. The values of the benzene, toluene, and xylene (BTX) and $i$-pentane emission factors are about $20 \%$ lower than given in another tunnel studies as indicated in Table 6 . This maybe due to the low fractions of gasoline-fueled vehicles in tunnels studied when compared to other studies. For propane and $i$-butane, the emission factors measured in our study are higher than previously measured in Taiwan and Switzerland. Due to the difference in fuel composition (i.e. 10\% of LPG fueled vehicles) in Hong Kong, significantly higher emission factors of propane and $i$-butane were anticipated and observed. This also demonstrates the need to establish local emission profiles.

\section{Conclusions}

Ethene, $i$-pentane and toluene were found to be the most abundant VOCs generated from the fueled vehicles. In this pilot vehicle source study, our observations are consistent with other studies done in Europe and Asian cities. But the average emission factor of OCS $\left(0.8 \mathrm{mg} \mathrm{veh}^{-1} \mathrm{~km}^{-1}\right)$ was higher than previous study done by chassis dynamometer. These emission factors provide reliable estimations of VOCs introduced into the atmosphere from vehicular sources. On the basis of $100 \mathrm{~g}$ VOCs emitted, ozone formation is $494 \mathrm{~g}$ (average emission rate of total VOCs is $115 \mathrm{mg} \mathrm{veh}^{-1} \mathrm{~km}^{-1}$ ) which is similar to the results of Taipei tunnel, of $427 \mathrm{~g}$. This information will be useful in determining emission controls for different classes of vehicles. This will also allow for estimating the impact of VOC emissions from non mobile sources.

Acknowledgements. This project is supported by the study of Determination of Suspended Particulate \& VOC Emission Profiles for Vehicular Sources in Hong Kong (Tender Ref. AS 02-342) funded by Hong Kong Environment Protection Department (HKEPD), the Research Grants Council of Hong Kong (PolyU5204/07E), the Hundred Talents Program (Observation and modeling of secondary organic aerosol formation in China - KZCX2-YW-BR-10) of the Chinese Academy of Sciences.

The authors are grateful to Judith C. Chow and John G. Watson for their significant contributions to our sampling plan, and to HKEPD for provision of the data sets and permission for publication. The content of this paper does not necessarily reflect the views and policies of the HKSAR Government, nor does mention of trade names or commercial products constitute endorsement or recommendation of use.

Edited by: A. Hofzumahaus 
Table 6. Comparison of emission factors of VOCs $\left(\mathrm{mg} \mathrm{veh}^{-1} \mathrm{~km}^{-1}\right)$ with other studies.

\begin{tabular}{|c|c|c|c|c|c|}
\hline & This Study & $\begin{array}{r}\text { Hwa et al., } \\
2002\end{array}$ & $\begin{array}{r}\text { Chiang et al., } \\
2007\end{array}$ & $\begin{array}{r}\text { Staehelin et al. } \\
1998\end{array}$ & $\begin{array}{r}\text { Staehelin et al. } \\
1998\end{array}$ \\
\hline Tunnel, Location & $\begin{array}{c}\text { Shing Mun } \\
\text { Tunnel, Hong } \\
\text { Kong }\end{array}$ & $\begin{array}{l}\text { Tai Pei } \\
\text { Tunnel, } \\
\text { Taiwan }\end{array}$ & $\begin{array}{r}\text { Chung-Liao } \\
\text { Tunnel, } \\
\text { Taiwan }\end{array}$ & $\begin{array}{r}\text { Gubrist } \\
\text { Tunnel, } \\
\text { Switzerland }\end{array}$ & $\begin{array}{r}\text { Gubrist } \\
\text { Tunnel, } \\
\text { Switzerland }\end{array}$ \\
\hline Year of Experiment & 2003 & 2000 & 2005 & 1993 & 1993 \\
\hline Type of Vehicle & $\begin{array}{l}\text { LPG, gasoline, } \\
\text { and diesel }\end{array}$ & $\begin{array}{r}\text { gasoline and } \\
\text { diesel }\end{array}$ & $\begin{array}{r}\text { gasoline and } \\
\text { diesel }\end{array}$ & gasoline & diesel \\
\hline ethene & 13 & 26 & - & 24 & 45 \\
\hline toluene & 12 & 29 & 29 & 16 & 21 \\
\hline$n$-butane & 8.7 & 6.6 & 5.1 & 9.7 & 27 \\
\hline propane & 5.7 & 2.4 & 0.2 & 0.15 & 5.7 \\
\hline$i$-pentane & 5.6 & 13 & 40 & 18 & 43 \\
\hline$i$-butane & 5.5 & 4.6 & - & 1.7 & 5.2 \\
\hline propene & 5.3 & 12 & 10 & 14 & 22 \\
\hline benzene & 4.5 & 12 & 5.9 & 10 & 15 \\
\hline ethyne & 4.0 & 12 & - & 13 & 16 \\
\hline 1,2,4-trimethylbenzene & 3.0 & 14 & 12 & 4.6 & 9.6 \\
\hline$m$-xylene & 2.6 & 9.0 & 8.4 & 11 & 27 \\
\hline$p$-xylene & 1.1 & - & & & \\
\hline$i$-butene & 2.5 & - & - & 8.0 & 11 \\
\hline 1-pentene & 1.9 & 1.6 & 0.97 & 0.61 & 3.4 \\
\hline 2-methylpentane & 1.8 & 5.3 & 13 & - & - \\
\hline ethane & 1.7 & 4.3 & - & 4.3 & 3.2 \\
\hline$n$-pentane & 1.7 & 9.5 & 19 & 6.2 & 16 \\
\hline 1-butene & 1.6 & 8.3 & 11 & 1.9 & 5.0 \\
\hline$o$-xylene & 1.6 & 7.9 & 6.4 & 4.8 & 6.3 \\
\hline 1,2,3-trimethylbenzene & 1.4 & - & 2.0 & 0.97 & 2.4 \\
\hline$n$-hexane & 1.3 & 4.2 & 5.7 & 1.7 & 2.9 \\
\hline ethylbenzene & 1.3 & 5.9 & 5.3 & 3.6 & 7.2 \\
\hline 3-methylpentane & 1.2 & 6.4 & 5.6 & - & - \\
\hline 2,2,4-trimethylpentane & 1.0 & 0.29 & 0.77 & - & - \\
\hline cylopentane & 1.0 & 0.89 & 2.0 & - & - \\
\hline$n$-heptane & 0.9 & 1.5 & 1.6 & 0.93 & 2.3 \\
\hline$n$-decane & 0.8 & - & 0.07 & 0.03 & 7.7 \\
\hline 1,3,5-trimethylbenzene & 0.8 & 2.3 & 3.7 & 1.5 & 2.7 \\
\hline 3-methylhexane & 0.8 & 2.9 & 2.8 & - & - \\
\hline$n$-nonane & 0.7 & 0.5 & 0.3 & 0.07 & 1.7 \\
\hline 2-methylhexane & 0.7 & - & 2.5 & - & - \\
\hline trans-2-butene & 0.6 & 1.6 & 0.81 & 1.4 & 2.9 \\
\hline$n$-octane & 0.5 & 1.3 & 0.78 & 0.22 & 1.4 \\
\hline$n$-propylbenzene & 0.5 & 1.7 & 1.7 & 0.68 & 1.9 \\
\hline cis-2-butene & 0.5 & 1.8 & 1.6 & 1.3 & 2.5 \\
\hline 1,3-butadiene & 0.3 & 2.6 & 3.8 & 1.6 & -1.6 \\
\hline 2,3-dimethylbutane & 0.3 & 1.3 & 13 & - & - \\
\hline cyclohexane & 0.3 & 0.98 & 0.4 & 4.5 & 6.1 \\
\hline 2,4-dimethylpentane & 0.2 & 0.44 & 0.9 & - & - \\
\hline isopropylbenzene & 0.1 & - & 1.2 & 0.18 & 0.26 \\
\hline 2,3-dimethylpentane & 0.1 & - & 0.72 & 8.6 & 16 \\
\hline
\end{tabular}




\section{References}

Borbon, A., Fontaine, H., Veillerot, M., Locoge, N., Galloo, J. C., and Guillermo, R.: An investigation into the traffic-related fraction of isoprene at an urban location, Atmos. Environ., 35, 37493760, 2001.

Barletta, B., Meinardi, S., Simpson, I. J., Khwaja, H. A., Blake, D. R., and Rowland, F. S.: Mixing ratios of volatile organic compounds (VOCs) in the atmosphere of Karachi, Pakistan, Atmos. Environ., 36, 3429-3443, 2002.

Barletta, B., Meinardi, S., Rowland, F. S., Chan, C. Y., Wang, X. M., Zou, S. C., Chan, L. Y., and Blake, D. R.: Volatile organic compounds in 43 Chinese cities, Atmos. Environ., 39, 5979-5990, 2005.

Carroll, M. A.: Measurements of $\mathrm{COS}$ and $\mathrm{CS}_{2}$ in the free troposphere, J. Geophys. Res., 90, 10483-10486, 1985.

Carter, W. P. L.: Development of ozone reactivity scales for volatile organic compounds, JAWMA, 44, 881-899, 1994.

Carter, W. P. L.: VOC reactivity data as of February 5, 2003 (available at: ftp://ftp.cert.ucr.edu/pub/carter/SAPRC99/r02tab. xls, last access: 15 August 2007, 2003.

Chan, L. Y., Chu, K. W., Zou, S. C., Chan, Y. C., Wang, X. M., Barletta, B., Blake, D. R., and Guo, H.: Characteristics of nonmethane hydrocarbons (NMHCs) in industrial, industrial-urban, and industrial-suburban atmospheres of the Pearl River Delta (PRD) region of south China, J. Geophys. Res., 111, D11304, doi:10.1029/2005JD006481, 2006.

Chan, C. Y., Chan, L. Y., Wang, X. M., Liu, Y. M., Lee, S. C., Zou, S. C., Sheng, G. Y., and Fu, J. M.: Volatile organic compounds in roadside microenvironments of metropolitan Hong Kong, Atmos. Environ., 36, 2039-2047, 2002.

Chiang, H.-L., Hwu, C.-S., Chen, S.-Y., Wu, M.-C., Ma, S.-Y., and Huang, Y. S.: Emission factors and characteristics of criteria pollutants and volatile organic compounds VOCs) in a freeway tunnel study, Sci. Total Environ., 381, 200-211, 2007.

Duffy, B. L. and Nelson, P. F.: Non-methane exhaust composition in the Sydney Harbour tunnel: a focus on benzene and 1,3butadiene, Atmos. Environ., 30, 2759-2768, 1996.

Finlayson-Pitts, B. J. and Pitts Jr, J. N.: Atmospheric Chemistry, Wiley, New York, 1986.

Fried, A., Henry, B., Sams, R.: Measurements of carbonyl sulfide in automotive emissions and an assessment of its importance to the global sulfur cycle, J. Geophys. Res., 92, 14621-14634, 1992.

Gertler, A. W., Fujita, E. M., Pierson, W. R., and Wittorf, D. N.: Appointment of NMHC tailpipe vs non-tailpipe emissions in the Fort McHenry and Tuscarora Mountain Tunnels, Atmos. Environ., 30, 2297-2305, 1996.

Guo, H., So, K. L., Simpson, I. J., Barletta, B., Meinardi, S., and Blake, D. R.: $\mathrm{C}_{1}-\mathrm{C}_{8}$ volatile organic compounds in the atmosphere of Hong Kong: Overview of atmospheric processing and source apportionment, Atmos. Environ., 41, 1456-1472, 2007.

Guo, H., Wang, T., Simpson, I. J., Blake, D. R., Kwok, Y. H., and Li, Y. S.: Regional and local source contributions to ambient NMHCs of a polluted rural/coastal site in Pearl River Delta, China, Atmos. Environ., 40, 2345-2359, 2006.

Guo, H., Lee, S. C., Louie, P. K. K., and Ho, K. F.: Characterization of hydrocarbons, halocarbons and carbonyls in the atmosphere of Hong Kong, Chemosphere, 57, 1363-1372, 2004.

Haszpra, L. and Szilagyi, I.: Non-methane hydrocarbon composition of car exhaust in Hungary, Atmos. Environ., 28, 2609-2614,
1994.

Heeb, N. V., Forss, A.-M., and Bach, C.: Fast and quantitative measurement of benzene, toluene and $\mathrm{C}_{2}$-benzenes in automotive exhaust during transient engine operation with and without catalytic exhaust gas treatment, Atmos. Environ., 33, 205-215, 1999.

Heeb, N. V., Forss, A.-M., Bach, C., and Mattrel, P.: Velocitydependent emission factors of benzene, toluene and $\mathrm{C}_{2}$-benzenes of a passenger car equipped with and without a regulated 3-way catalyst, Atmos. Environ., 34, 1123-1137, 2000.

Ho, K. F., Lee, S. C., Guo, H., and Tsai, W. Y.: Seasonal and diurnal variations of volatile organic compounds (VOCs) in the atmosphere of Hong Kong, Sci. Total Environ., 322, 155-166, 2004.

Ho, K. F. and Lee, S. C.: Identification of atmospheric volatile organic compounds (VOCs), polycyclic aromatic hydrocarbons (PAHs) and carbonyl compounds in Hong Kong, Sci. Total Environ., 289, 145-158, 2002.

Hsu, Y. C., Tsai, J. H., Chen, H. W., and Lin, W. Y.: Tunnel study of on-road vehicle emissions and the photochemical potential in Taiwan, Chemosphere, 42, 227-234, 2001.

Hwa, M.-Y., Hsieh, C.-C., Wu, T.-C., and Chang, L. F. W.: Realworld vehicle emissions and VOCs profile in the Taipei tunnel located at Taiwan Taipei area, Atmos. Environ., 36, 1993-2002, 2002.

Kaiser, E. W., Siegl, W. O., Cotton, D. F., and Anderson, R. W.: Effect of fuel structure on emissions from a spark-ignited engine, 2, Naphthene and aromatic fuels, Environ. Sci. Technol., 26, 15811586, 2002.

Kirchstetter, T. W., Singer, B. C., Harley, R. A., Kendall, G. R., and Chan, W.: Impact of oxygenated gasoline use on California light-duty vehicle emissions, Environ. Sci. Technol., 30, 661670, 1996.

Lee, S. C., Chiu, M. Y., Ho, K. F., Zou, S. C., and Wang, X. M.: Volatile organic compounds (VOCs) in urban atmosphere of Hong Kong, Chemosphere, 48, 375-382, 2002.

Lee, S. C., Ho, K. F., Chan, L. Y., Zielinska, B., and Chow, J. C.: Polycyclic aromatic hydrocarbons (PAHs) and carbonyl compounds in urban atmosphere of Hong Kong, Atmos. Environ., 35, 5949-5960, 2001.

Liu, Y., Shao, M., Fu, L. L., Lu, S. H., Zeng, L. M., and Tang, D. G.: Source profiles of volatile organic compounds (VOCs) measured in China: Part I, Atmos. Environ., 42, 6247-6260, 2008.

Lonneman, W. A., Sella, R. L., and Meeks, S. A.: Non-methane organic composition in the Lincoln tunnel, Environ. Sci. Technol., 20, 790-796, 1986.

Monod, A., Sive, B. C., Avino, P., Chen, T., Blake, D. R., and Rowland, F. S.: Volatile organic compounds in some urban locations in United States, Chemosphere, 47, 863-882, 2002.

Mu, Y., Wu, H., Zhang, X., and Jiang, G.: Impact of anthropogenic sources on carbonyl sulfide in Beijing City, J. Geophys. Res., 107(D24), 4769, doi:10.1029/2002JD002245, 2002.

Mugica, V., Vega, E., Arriaga, J. L., and Ruiz, M. E.: Determination of motor vehicle profiles for non-methane organic compounds in the Mexico city metropolitan area, JAWMA, 48, 1060-1068, 1998.

Na, K., Kim, Y. P., and Moon, K. C.: Seasonal variation of the $\mathrm{C}_{2}-$ $\mathrm{C}_{9}$ hydrocarbon concentrations and compositions emitted from motor vehicles in a Seoul tunnel, Atmos. Environ., 36, 19691978, 2002. 
Nelson, P. F. and Quigley, S. M.: The m, p-xylenes: ethylbenzene ratio, a technique for estimating hydrocarbon age in ambient atmospheres, Atmos. Environ., 17, 659-662, 1983.

Ning, Z., Polidori, A., Schauer, J. J., James, J., Sioutas, C.: Emission factors of PM species based on freeway measurements and comparison with tunnel and dynamometer studies, Atmos. Environ., 42, 3099-3114, 2008.

Pierson W. R. and Brachaczek W. W.: Particulate matter associated with vehicles on the road, Environ. Sci. Technol., 17, 757-760, 1983.

Pierson, W. R., Gertler, A. W., and Bradow, R. L.: Comparison of the SCAQS tunnel study with other on-road vehicle emission data, JAWMA, 40, 1495-1504, 1990.

Pierson, W. R., Gertler, A. W., Robinson, N. F., Sagebiel, J. C., Zielinska, B., Bishop, G. A., Stedman, D. H., Zweidinger, R. B., and Ray, W. D.: Real-world automotive emissions - Summary of studies in the Fort McHenry and Tuscarora Mountain Tunnels, Atmos. Environ., 30, 2233-2256, 1996.

Rogak, S. N, Pott, U., Dann, T., and Wang, D.: Gaseous emissions from vehicles in a traffic tunnel in Vancouver, British Columbia, JAWMA, 48, 604-615, 1998.

Schauer, J. J., Kleeman, M. J., Cass, G. R., and Simoneit, B. R. T.: Measurement of emissions from air pollution sources, 2, $\mathrm{C}_{1}$ through $\mathrm{C}_{30}$ organic compounds from medium duty diesel trucks, Environ. Sci. Technol., 33, 1578-1587, 1999.

Smyth, S., Sandholm, S., Shumaker, B., Mitch, W., Kanvinde, A., Bradshaw, J., Liu, S., McKeen, S., Gregory, G., Anderson, B., Talbot, R., Blake, D., Rowland, S., Browell, E., Fenn, M., Merrill, J., Bachmeier, S., Sachse, G., and Collins, J.: Characterization of the chemical signatures of air masses observed during the PEM experiments over the western Pacific, J. Geophys. Res., 104, 16243-16254, 1999.

So, K. L. and Wang, T.: $\mathrm{C}_{3}-\mathrm{C}_{12}$ non-methane hydrocarbons in subtropical Hong Kong: spatial-temporal variations, source-receptor relationships and photochemical reactivity, Sci. Total Environ., 328, 161-174, 2004.

Staehelin, J., Keller, C., Stahel, W., Schlapfer, K., and Wunderli, S.: Emission factors from road traffic from a tunnel study (Gubrist tunnel, Switzerland) Part III: results of organic compounds, $\mathrm{SO}_{2}$ and speciation of organic exhaust emission, Atmos. Environ., 32, 999-1009, 1998.
Stemmler, K., Bugmann, S., Buchmann, B., Reimann, S., and Staehelin, J.: Large decrease of VOC emissions of Switzerland's car fleet during the past decade: results from a highway tunnel study, Atmos. Environ., 39, 1009-1018, 2005.

Stoeckenius, T. E., Ligocki, M. P., Shepard, S. B., and Iwamiya, R. K.: Analysis of PAMS data: application to summer 1993 Houston and Baton Rouge data, Draft report prepared by Systems Applications International, San Rafael, CA, SYSAPP 94-95/115d, November, in: USEPA report: Receptor Modeling, 2006.

Thijsse, T. R., van Oss, R. F., and Lenschow, P.: Determination of source contributions to ambient volatile organic compound concentrations in Berlin, JAWMA, 49, 1394-1404, 1999.

Transport Department: Annual Transport Digest 2004, The Transport Department of Hong Kong SAR, 2004.

Tsai, J.-H., Chiang, H.-L., Hsu, Y.-C., Weng, H.-C., and Yang, C.Y.: The speciation of volatile organic compounds (VOCs) from motorcycle engine exhaust at different driving modes, Atmos. Environ., 37, 2485-2496, 2003.

Tsai, W. Y., Chan, L. Y., Blake, D. R., and Chu, K. W.: Vehicular fuel composition and atmospheric emissions in South China: Hong Kong, Macau, Guangzhou, and Zhuhai, Atmos. Chem. Phys., 6, 3281-3288, 2006, http://www.atmos-chem-phys.net/6/3281/2006/.

Tsai, W. Y.: Non-methane hydrocarbon characteristics of motor vehicular emissions in the Pearl River Delta region, $\mathrm{PhD}$ thesis, 2007.

Turrio-Baldassarri, L., Battistelli, C. L., Chiara, L., Conti, L., Crebelli, R., De Berardis, B., Iamiceli, A. L., Gambino, M., and Iannaccone, S.: Emission comparison of urban bus engine fueled with diesel oil and "biodiesel" blend, Sci. Total Environ., 327, 147-162, 2004.

Vega, E., Mugica, V., Carmona, R., and Valencia, E.: Hydrocarbon source apportionment in Mexico city using the chemical mass balance receptor model, Atmos. Environ., 34, 4121-4129, 2000. 